\title{
FAKTOR-FAKTOR YANG MEMPENGARUHI KUALITAS LAPORAN KEUANGAN PEMERINTAH DAERAH DENGAN SISTEM PENGENDALIAN INTERNAL PEMERINTAH SEBAGAI PEMODERASI (STUDI EMPIRIS PADA OPD DIKABUPATEN KUBURAYA)
}

\author{
ANGGA PERMADI KAPRIANA \\ Universitas Tanjungpura \\ ISKANDAR AGUNG \\ Universitas Tanjungpura
}

\begin{abstract}
Tujuan dari penelitian ini adalah untuk menguji pengaruh kompetensi sumber daya manusia, standar akuntansi pemerintahan dan sistem akuntansi keuangan daerah terhadap kualitas laporan keuangan pemerintah daerah dengan sistem pengendalian internal pemerintah sebagai pemoderasi. Data yang digunakan dalam penelitian ini adalah data primer. Metode pengumpulan data dilakukan dengan memberikan pertanyaan tertulis berupa kuesioner kepada responden. Populasi penelitian ini adalah seluruh pegawai bagian keuangan yang berada di tiap OPD Pemerintah Kabupaten Kubu Raya. Pemilihan sampel penelitian ini menggunakan teknik purposive sampling dan sampel yang diperoleh ada sebanyak 85 pegawai. Teknik analisis data dilakukan dengan metode Structural Equation Modelling (SEM) dengan pendekatan Partial Least Squares (PLS) menggunakan perangkat lunak WarpPLS 6.0. Hasil penelitian menunjukkan bahwa standar akuntansi pemerintahan dan sistem akuntansi keuangan daerah berpengaruh positif dan signifikan terhadap kualitas laporan keuangan pemerintah daerah, sedangkan kompetensi sumber daya manusia tidak berpengaruh terhadap kualitas laporan keuangan pemerintah daerah. Sistem pengendalian internal pemerintah tidak dapat memoderasi pengaruh standar akuntansi pemerintahan terhadap kualitas laporan keuangan pemerintah daerah tetapi, sistem pengendalian internal pemerintah dapat memoderasi pengaruh kompentensi sumber daya manusia dan sistem akuntansi keuangan daerah terhadap kualitas laporan keuangan pemerintah daerah..
\end{abstract}

Keywords: Kompetensi Sumber Daya Manusia, Standar Akuntansi Pemerintahan, Sistem Akuntansi Keuangan Daerah, Sistem Pengendalian Internal Pemerintah dan Kualitas Laporan, Keuangan Pemerintah Daerah 


\section{PENDAHULUAN}

Sistem penyelenggaraan pemerintah daerah yang awalnya bersifat sentralisasi lalu kemudian berubah menjadi desentralisasi mengharuskan di laksanakannya otonomi daerah. Otonomi daerah yang dimaksud merupakan pemberian hak, wewenang maupun kewajiban daerah dari pemerintah pusat ke pemerintah daerah untuk secara langsung mengurus dan mengatur sendiri urusan pemerintahannya sesuai peraturan perundang-udangan yang ada. Pelaksanaan yang di lakukan pemerintah daerah dalam menjalankan otonomi daerah menjadikan pemerintah daerah wajib untuk mengelola keuangannya sendiri sehingga dalam pelaksanaan pengelolaan keuangan, pemerintah daerah harus mengelola keuangannya secara tertib pada ketentuanketentuan peraturan perundang-undangan yang ada. Sehingga pemerintah daerah diwajibkan untuk menyusun Laporan Keuangan Pemerintah Daerah (LKPD).

Laporan keuangan disusun untuk memperoleh gambaran informasi mengenai posisi keuangan seperti posisi harta, utang, dan modal yang terjadi dalam pemerintah daerah tersebut serta mengetahui hasil-hasil yang telah dicapai oleh pemerintah daerah selama tahun anggaran yang bersangkutan. Pemerintah daerah berkewajiban mempublikasikan informasi berdasarkan laporan keuangan sebagai dasar pengambilan keputusan sehingga informasi yang dipublikasikan tersebut dapat dimanfaatkan oleh para pemakai dan stackholders (Fuad, 2016: 5).

Faktor kompetensi sumber daya manusia menjadi sangat penting untuk menciptakan laporan keuangan yang berkualitas karena sumber daya manusia merupakan elemen terpenting dari sebuah organisasi sehingga peningkatan pengelolaan sumber daya manusia menjadi sesuatu yang wajib dilakukan. Selain itu penerapan standar akuntansi pemerintahan juga memiliki pengaruh penting terhadap kualitas laporan keuangan karena SAP merupakan pedoman bagi pemerintah daerah yang mempunyai kekuatan hukum dalam proses penyusunan laporan keuangan. Faktor sistem akuntansi keuangan daerah juga yang menjadi faktor keberhasilan laporan keuangan yang berkualitas karena mampu memberikan output data berupa laporan keuangan pemerintah daerah. Kompetensi sumber daya manusia, standar akuntansi pemerintah dan sistem akuntansi keuangan daerah dapat di kaitkan dengan sistem pengendalian internal pemerintah yang merupakan 
metode yang dipakai untuk dapat mengawasi dan memberikan keyakinan bagi tercapainya tujuan suatu organisasi yang telah direncanakan sebelumnya.

\section{KAJIAN LITERATUR}

\section{Teori Keagenan (Agency Theory)}

Agency theory merupakan teori yang menjelaskan tentang hubungan antara pihak prinsipal dan agen, yang dimana prinsipal adalah pihak yang memberikan atau mendelegasikan tanggungjawab di dalam pengambilan keputusan kepada agen, dan setelah itu hak dan kewajiban kedua belah pihak diuraikan dalam suatu perjanjian kerja yang saling menguntungkan. Jensen dan Meckling (1976) menjelaskan hubungan keagenan merupakan suatu kontrak dimana satu orang atau lebih yang di sebut sebagai prinsipal kemudian memerintahkan kepada orang lain yaitu disebut sebagai agen untuk melakukan sebuah jasa atas nama prinsipal sebagai yang memberi perintah maupun yang memberi wewenang kepada agen untuk membuat keputusan yang terbaik bagi pihak prinsipal. Di dalam pelaporan keuangan, pemerintah daerah yang bertindak sebagai agen mempunyai kewajiban untuk menyajikan laporan keuangan yang berkualitas dengan berisi informasi yang bermanfaat bagi para pengguna informasi keuangan pemerintah daerah yang betindak sebagai prinsipal yang menilai laporan keuangan yang telah disajikan apakah sudah transparan dan akuntabilitas serta bisa digunakan untuk membuat keputusan dalam aspek ekonomi, sosial mapun politik.

\section{Teori Kepatuhan}

Menurut Tyler dalam Septiani (2005) terdapat dua perspektif dasar dalam literatur sosiologi mengenai teori kepatuhan yaitu merupakan instrumental dan normatif. Perspektif instrumental mengasumsikan individu secara utuh didorong oleh kepentingan pribadi dan tanggapan terhadap perubahan-perubahan dalam tangible, insentif, dan penalti yang berhubungan dengan perilaku. Perspektif normatif berhubungan dengan apa yang orang anggap sebagai moral dan berlawanan dengan kepentingan pribadi mereka. Seorang individu cenderung mematuhi hukum yang mereka anggap sesuai dan konsisten dengan norma-norma internal mereka.

\section{Kualitas Laporan Keuangan}

Laporan keuangan merupakan hasil akhir dari proses pencatatan yang merupakan suatu ringkasan dari transaksi-transaksi keuangan yang terjadi selama tahun buku yang 
bersangkutan. Menurut Bastian (2010: 96), laporan keuangan yaitu representasi posisi keuangan terhadap transaksi- transaksi yang dilakukan oleh suatu entitas.Berdasarkan Peraturan Menteri Dalam Negeri Nomor 71 Tahun 2010, laporan keuangan pemerintah daerah terdiri dari: Laporan Realisasi Anggaran, Laporan Perubahan Saldo Anggaran Lebih, Neraca,Laporan Operasional,Laporan Arus Kas,laporan perubahan ekuitas dan Catatan atas laporan keuangan.

Laporan keuangan memiliki keempat karakteristik kualitatif yaitu: 1) relevan, yang berarti informasi laporan keuangan yang termuat didalamnya dapat mempengaruhi keputusan pengguna dengan membantunya dalam melakukan evaluasi peristiwa masa lalu atau masa kini dan memprediksi di masa yang akan datang 2) andal, yang berarti penyajian informasi laporan keuangan tersebut dapat memenuhi syarat harus bebas serta tak terikat dengan pengertian yang salah maupun menyesatkan (salah penyajian), kemudian dapat menampilkan berbagai fakta yang ada secara jelas dan jujur, serta informasi yang telah di sesuaikan dengan ketetapan yang ada 3) dapat dibandingkan, yang berarti dapat membandingkan laporan keuangan periode saat ini dengan sebelumnya serta bisa dilakukan perbandingan terhadap laporan keuangan entitas lain 4) dapat dipahami, yang berarti informasi di dalam laporan keuangan tersebut mampu mengiterprestasikan apa yang terdapat di laporan keuangan sehingga mudah untuk dipahami serta dimengerti oleh penggunanya atau stackholders terkait.

\section{Kompetensi Sumber Daya Manusia}

Kompetensi merupakan karakteristik yang dimiliki seseorang sebagai sebuah kecakapan, keterampilan, maupun kemampuan untuk mengeluarkan kinerja yang superior dalam pekerjaannya. McClelland dalam Rivai (2011:299) mendefinisikan bahwa kompetensi sebagai karakteristik mendasar yang harus dimiliki seseorang dan dapat berpengaruh langsung, serta dapat memprediksikan peningkatan kinerja yang sangat. Kemudian menurut Nawawi (2001: 57) sumber daya manusia adalah seorang manusia ataupun orang yang bekerja dan menjadi anggota pada organisasi tersebut, lalu kemudian biasa disebut dengan personil, pegawai, karyawan, tenaga kerja, dan lain-lain. Kompetensi sumber daya manusia (pegawai) terdapat tiga indikator dengan dasar menurut keputusan Kepala BKN Nomor 46A Tahun 2007 yaitu pengetahuan, keterampilan dan sikap. 


\section{Standar Akuntansi Pemerintahan}

Berdasarkan dengan UU Nomor 22 Tahun 1999 yang sekarang direvisi menjadi UU Nomor 32 Tahun 2004, kemudian PP Nomor 105 Tahun 2000 dan UU Nomor 17 Tahun 2003, penyusunan penyajian laporan keuangan pusat dan daerah didasarkan pada standar akuntansi pemerintah yang berarti dapat disimpulkan bahwa standar akuntansi pemerintah digunakan sebagai alat untuk memfalisitasi pelaporan yang semakin transparan dan akuntabel (Bastian, 2006). Dengan adanya standar yang telah diberlakukan ini perbandingan dan pengukuran antar pelaporan keuangan dapat bisa dilakukan, sehingga praktek KKN (korupsi, kolusi, nepotisme) dapat dicegah dalam sistem pengelolaan keuangan negara. Komite Standar Akuntansi Pemerintah (KSAP) telah menyusun Pernyataan Standar Akuntansi Pemerintahan (PSAP) dan telah ditetapkan dalam bentuk Peraturan Pemerintah No. 71 tahun 2010 Standar Akuntansi pemerintah berbasis akrual dengan disusun keduabelas PSAP yaitu sebagai berikut : PSAP 01 Penyajian Laporan Keuangan, PSAP 02 Laporan Realisasi Anggaran, PSAP 03 Laporan Arus Kas, PSAP 04 Catatan Atas Laporan Keuangan, PSAP 05 Akuntansi Persediaan, PSAP 06 Akuntansi Investasi, PSAP 07 Akuntansi Aset Tetap, PSAP 08 Akuntansi Konstruksi dalam Pengerjaan, PSAP 09 Akuntansi Kewajiban. METODE PENELITIAN

Bentuk penelitian yang digunakan dalam penelitian ini adalah comparative research atau penelitian komparatif dengan pendekatan kuantitatif dan kualitatif. Penelitian komparatif yakni menganalisa data dengan membandingkan antara dua variabel atau lebih terhadap suatu variabel dengan pengujian hipotesis dan data yang dipakai berupa angka-angka yang dihitung memakai metode uji statistik (Nazir, 2005). Sedangkan penelitian kualitatif ialah metode penelitian yang berlandaskan pada filsafat postpositivisme, digunakan untuk meneliti pada obyek yang alamiah, dimana peneliti adalah sebagai instrumen kunci, pengambilan sampel sumber data dilakukan secara purposive dan snowball, teknik penelitian trianggulasi (gabungan), analisis data bersifat induktif/kualitatif, dan hasil penelitian kualitatif lebih menekankan makna daripada generalisasi (Sugiyono, 2008).

Data dalam penelitian ini bersumber dari internal perusahaan. Menurut Sugiyono (2016) data internal, yaitu data yang menggambarkan keadaan atau kegiatan dalam 
sebuah organisasi. Data internal dalam penelitian ini diperoleh dengan cara mengunduh laporan keuangan kedua perusahaan melalui situs resmi masing-masing perusahaan yang dapat diakses melalui www.telkom.co.id untuk PT Telkom Tbk dan www.indosatooredoo.com untuk PT Indosat Tbk. Laporan keuangan kedua perusahaan juga dapat diakses dan diunduh melalui situs resmi Bursa Efek Indonesia yang dapat diakses di www.idx.co.id.

Data dalam penelitian ini menggunakan data sekunder. Data-data diambil dan dijadikan sampel dalam penelitian ini, kemudian data-data tersebut diolah dengan menggunakan aplikasi Statistical Package for Social Science (SPSS) sehingga olahan data akan dihasilkan dalam bentuk tabel, grafik, serta kesimpulan yang berfungsi untuk mengambil keputusan atas hasil analisis. Teknik analisis data pada penelitian ini menggunakan uji statistik deskriptif, uji asumsi klasik, uji hipotesis dan analisis kualitatif komparatif.

\section{Sistem Akuntansi Keuangan Daerah}

UU Nomor 17 Tahun 2013 tentang keuangan negara bahwa sistem akuntansi keuangan daerah merupakan aplikasi yang memiliki peran sangat penting dalam hal pengelolaan keuangan daerah. Menurut Hasanah dan Fauzi (2016:180) sistem akuntansi keuangan pemerintah daerah merupakan sistem akuntansi baik secara manual maupun terkomputerisasi yang telah memiliki tahapan-tahapan atau prosedural diperangkat dan juga peraturan yang harus diikuti dalam rangka mengumpulkan dan mencatat transaksi keuangan daerah kemudian mengelolah data tersebut menjadi berbagai laporan keuangan untuk pihak luar maupun internal pemerintah daerah sebagai akuntabilitas pelaksanaan anggaran pendapatan belanja daerah dan anggaran lain yang terkait dengan keuangan daerah. sistem akuntansi keuangan daerah menurut Permendagri Nomor 13 Tahun 2006 memiliki empat prosedur yaitu prosedur akuntansi penerimaan kas, prosedur akuntansi pengeluaran kas, prosedur akuntansi aset tetap dan terakhir prosedur akuntansi selain kas.

\section{Sistem Pengendalian Internal Pemerintah}

Berdasarkan Peraturan Pemerintah Nomor 60 Tahun 2008 tentang sistem pengendalian internal pemerintah (SPIP) yaitu sebuah proses yang integral pada tindakan dan kegiatan yang dilakukan secara terus menerus oleh pimpinan dan seluruh pegawai untuk memberikan keyakinan memadai atas tercapainya tujuan organisasi melalui 
kegiatan yang efektif dan efisien, keandalan pelaporan keuangan, pengamanan asset negara, dan ketaatan terhadap peraturan perundang-undangan yang meliputi yaitu lingkungan pengendaian, penilaian resiko, kegiatan pengendalian, informasi dan komunikasi, pemantauan pengendalian internal.

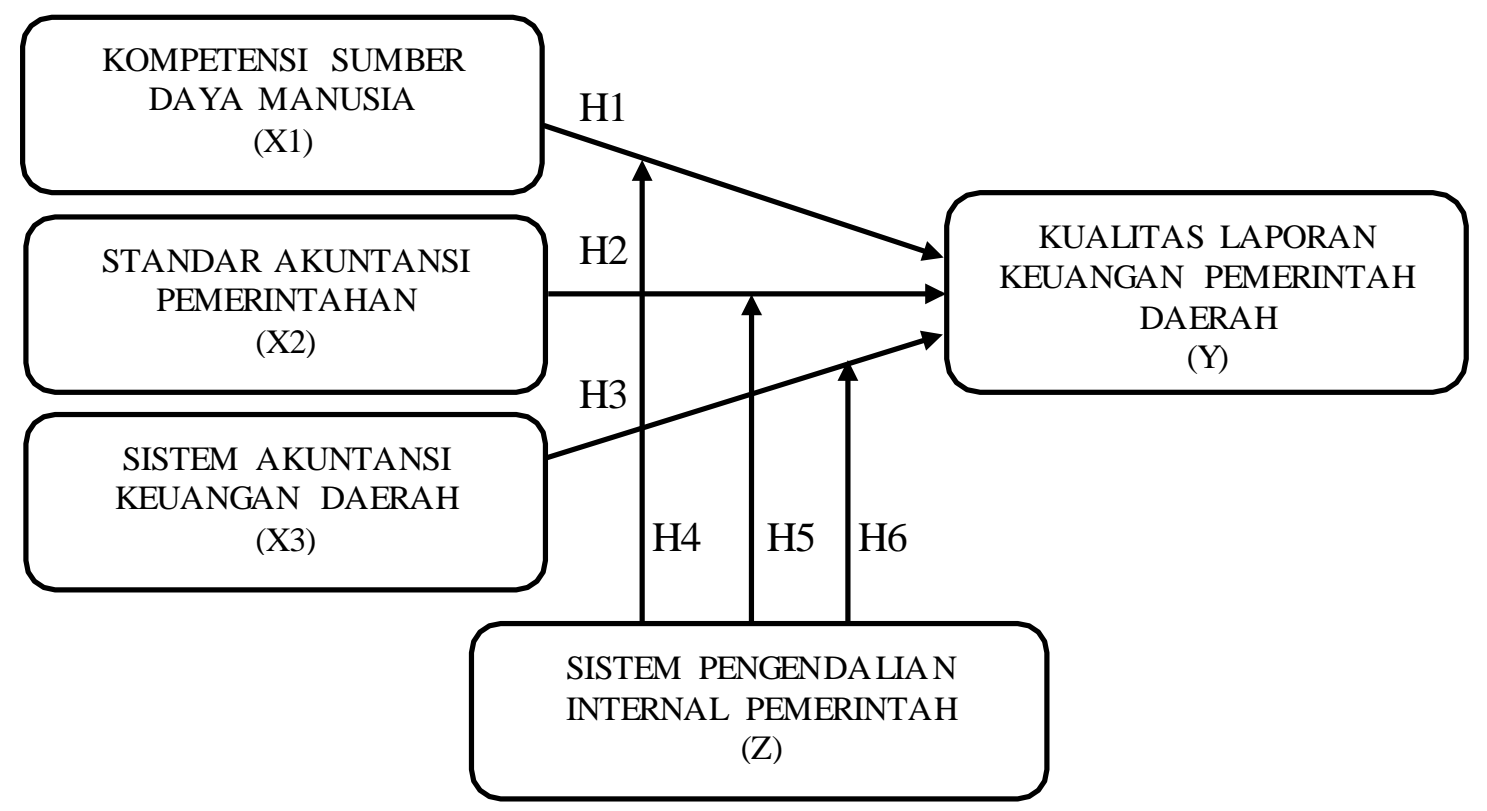

\section{Gambar 2.1 Model Kerangka Pemikiran Penelitian}

Keterangan :

$$
\begin{aligned}
& \underset{(\mathrm{Y}) \text { : Variabel Dependen }}{\longrightarrow} \text { : Garis Regresi } \\
& (\mathrm{Z}) \text { : Variabel Moderasi } \\
& (\mathrm{X}) \text { : Variabel Independen }
\end{aligned}
$$

\section{Hipotesis Penelitian}

\section{Pengaruh Kompetensi Sumber Daya Manusia terhadap Kualitas Laporan Keuangan Pemerintah Daerah}

Kompetensi sumber daya manusia merupakan kemampuan yang dimiliki seseorang pegawai yang berhubungan dengan pengetahuan, keterampilan serta sikap yang dapat mempengaruhi secara langsung terhadap kinerjanya demi tercapainya tujuan yang telah 
ditetapkan. Mahardini dan Miranti (2018) menyatakan bahwa kompetensi sumber daya manusia berpengaruh terhadap kualitas laporan keuangan. (Pujanira, 2017) membuktikan juga jika semakin baik kompetensi sumber daya manusia, maka hasil laporan keuangan pemerintah daerah akan berkualitas.

H1 : kompetensi sumber daya manusia berpengaruh positif terhadap kualitas laporan keuangan pemerintah daerah

\section{Pengaruh penerapan Standar Akuntansi Pemerintahan terhadap Kualitas}

\section{Laporan Keuangan Pemerintah Daerah}

SAP sebagai persyaratan yang mempunyai kekuatan hukum dalam upaya peningkatan kualitas laporan keuangan pemerintah di Indonesia. Penerapan standar akuntansi pemerintah yang sudah sesuai akan menghasilkan kualitas yang handal dalam penyusunan laporan keuangan (Hanaffi, 2017). Penelitian yang dilakukan oleh Rahmawati (2018) menyatakan adanya hubungan penerapan standar akuntansi pemerintah terhadap kualitas laporan keuangan pemerintah daerah. Hasil penelitian ini didukung dengan penelitian yang dilakukan oleh (Hanaffi, 2017). Hal ini membuktikan SAP jika diterapkan dengan benar maka hasil laporan keuangan pemerintah daerah akan berkualitas.

H2 : penerapan standar akuntansi pemerintahan berpengaruh positif terhadap kualitas laporan keuangan pemerintah daerah

\section{Pengaruh Pemanfaatan Sistem Akuntansi Keuangan Daerah terhadap}

\section{Kualitas Laporan Keuangan Pemerintah Daerah}

Menurut Silviana (2013), pemanfaatan sistem informasi akuntansi yang benar akan memudahkan dalam menyediakan informasi yang handal, akurat dan dapat dipertanggungjawabkan sehingga dapat menghasilkan laporan keuangan yang berkualitas. Penelitian yang dilakukan oleh Pujanira (2017) menyatakan bahwa sistem akuntansi keuangan daerah berpengaruh terhadap kualitas laporan keuangan pemerintah daerah. Hasil penelitian ini didukung dengan penelitian yang dilakukan juga oleh Yensi (2014). Hal ini membuktikan bahwa jika pemanfaatan sistem akuntansi keuangan pemerintah sudah diterapkan dengan sesuai standar yang ada, maka dapat menghasilkan laporan keuangan pemerintah daerah yang disajikan akan berkualitas. 
H3 : pemanfaatan sistem akuntansi keuangan daerah berpengaruh positif terhadap kualitas laporan keuangan pemerintah daerah.

Pengaruh Interaksi Kompetensi Sumber Daya Manusia dan Sistem Pengendalian Internal te rhadap Kualitas Laporan Keuangan Pemerintah Daerah

Kompetensi sumber daya manusia menjadi faktor penting keberhasilan didalam sebuah organisasi, karena sumber daya manusia yang berkompeten dibidangnya akan menjadikan pencapaian tujuan pada organisasi dapat terlaksana dengan benar. Jika dikaitkan dengan teori kepatuhan maka sistem pengendalian internal pemerintah sebagai sistem yang mengawasi kepatuhan pegawai untuk tetap mempertahankan kompetensi yang baik dalam menghasilkan laporan keuangan yang berkualitas.

$\mathrm{H} 4$ : sistem pengendalian internal pemerintah memoderasi pengaruh kompetensi sumber daya manusia terhadap kualitas laporan keuangan pemerintah daerah.

\section{Pengaruh Interaksi penerapan Standar Akuntansi Pemerintah dan Sistem Pengendalian Internal terhadap Kualitas Laporan Keuangan Pemerintah Daerah}

Standar akuntansi pemerintahan yang merupakan pedoman bagi pegawai bagian keuangan dalam penyusunan laporan keuangan pemerintah daerah menjadi faktor penting demi terwujudnya laporan keuangan yang berkualitas. Jika dikaitkan dengan teori kepatuhan maka sistem pengendalian internal pemerintah sebagai sistem yang mengawasi kepatuhan pemerintah daerah khususnya pada pegawai bagian keuangan yang menyusun laporan keuangan daerah wajib untuk menerapkan standar akuntansi pemerintah yang menjadi pedoman agar penyajian laporan keuangan pemerintah daerah dapat berkualitas.

H5 : sistem pengendalian internal pemerintah memoderasi pengaruh penerapan standar akuntansi pemerintah terhadap kualitas laporan keuangan pemerintah daerah

Pengaruh Interaksi pemanfaatan Sistem Akuntansi Keuangan Daerah dan

Sistem Pengendalian Internal terhadap Kualitas Laporan Keuangan Pemerintah Daerah 
Sistem akuntansi keuangan daerah berdasarkan Hasanah dan Fauzi (2016:18) bertujuan untuk meningkatkan efisiensi dan efektivitas dalam proses penyusunan laporan keuangan, dapat memudahkan kegiatan operasi rutin harian, melind ungi aset pemerintah lebih baik, serta peningkatan kualitas laporan keuangan dan kualitas di dalam pengambilan keputusan. Jika dikaitkan dengan teori kepatuhan maka sistem pengendalian internal pemerintah sebagai sistem yang mengawasi kepatuhan pegawai terhadap pemanfaatan sistem akuntansi keuangan daerah yang di laksanakan telah benar dan dapat meningkatkan kualitas laporan keuangan.

H6 : sistem pengendalian internal pemeritah memoderasi pengaruh pemanfaatan sistem akuntansi keuangan daerah terhadap kualitas laporan keuangan pemerintah daerah

\section{METODOLOGI PENELITIAN}

Penelitian ini tergolong penelitian dengan metode kausal komparatif (causalcomparative research) dengan teknik survey dengan pendekatan kuantitatif. Penelitian ini dilakukan dilingkungan Organsasi Perangkat Daerah (OPD) Kabupaten Kubu Raya Provinsi Kalimantan Barat.

Populasi dikatakan sebagai wilayah generalisasi yang terdiri atas objek atau subjek yang mempunyai kualitas dan karakteristik tertentu yang ditetapkan oleh peneliti untuk dipelajari dan ditarik kesimpulannya (Sangadji dan Sopiah, 2011:185). Adapun populasi dalam penelitian ini yaitu seluruh pegawai bagian keuangan di OPD Kabupaten Kubu Raya Provinsi Kalimantan Barat yang terdiri dari 1 Sekretariat Daerah, 1 Sekretariat DPRD, 1 Inspektorat, 4 Badan, 17 Dinas, 1 Satuan Polisi Pamong Praja, 1 Rumah Sakit Umum Daerah, 9 Kecamatan. Sedangkan Sampel adalah bagian dari jumlah dan karakteristik yang dimiliki oleh populasi. Dalam penelitian ini sampel diambil menggunakan teknik purposive sampling, yaitu teknik pengambilan sampel yang didasarkan pada kriteria tertentu (Sangadji dan Sopiah, 2011:188). Berdasarkan teknik tersebut, maka kriteria penentuan sampel dalam penelitian ini adalah: (1) Responden dalam penelitian ini adalah seluruh pegawai bagian keuangan yang bekerja di OPD Kabupaten Kubu Raya Provinsi Kalimantan Barat. (2) Responden tidak dibatasi oleh jabatan pegawai, yang terpenting bekerja di bidang keuangan.

Teknik analisis data dilakukan dengan metode Structural Equation Modelling (SEM) dengan pendekatan Variance Based SEM atau yang lebih dikenal dengan Partial 
Least Squares (PLS). Model analisis jalur semua variabel laten dalam PLS terdiri dari tiga set hubungan yaitu inner model, Outer model,Weight relation. Adapun perangkat lunak yang digunakan untuk menganalisis data penelitian untuk menguji hipotesis yaitu WarpPLS 6.0. kemudian dengan pengujian validitas dan realibilitas serta analis is statistik deskriptif.

Uji hipotesis digunakan untuk menjelaskan arah hubungan antara variabel ind ependen dan variabel dependennya. Pengujian ini dilakukan dengan cara analisis jalur (path analysis) atas model yang telah dibuat. Teknik SEM dapat secara simultan menguji model struktural yang komplek, sehingga dapat diketahui hasil analisis jalur dalam satu kali analisis regresi. Tingkat signifikansi yang dipakai dalam penelitian ini adalah sebesar 5\%. Dalam penelitian ini ada kemungkinan mengambil keputusan yang salah sebesar 5\% dan kemungkinan mengambil keputusan yang benar sebesar 95\%. Dasar pengambilan keputusan yaitu $p$-value $\leq 0,05$ hipotesis diterima sebaliknya $\geq 0,05$ hipotesis ditolak.

\section{HASIL PENELITIAN DAN PEMBAHASAN}

\section{Hasil Penelitian}

Responden dalam penelitian ini adalah seluruh pegawai bagian keuangan di tiap OPD pada pemerintahan Kabupaten Kubu Raya.

Tabel 4.1 Rincian Penyebaran dan Pengembalian Kuesioner

\begin{tabular}{|l|c|c|}
\hline & Jumlah & Persentase \\
\hline $\begin{array}{l}\text { Jumlah Kuesioner yang di } \\
\text { sebar }\end{array}$ & 101 & $100 \%$ \\
\hline $\begin{array}{l}\text { Jumlah Kuesioner yang } \\
\text { Tidak Kembali }\end{array}$ & 14 & $86 \%$ \\
\hline $\begin{array}{l}\text { Jumlah Kuesioner yang } \\
\text { kembali }\end{array}$ & 87 & $84 \%$ \\
\hline $\begin{array}{l}\text { Jumlah kuesioner yang } \\
\text { digunakan untuk penelitian }\end{array}$ & 85 & \\
\hline
\end{tabular}

Sumber: Data olahan, 2019 


\section{Validitas dan Reliabilitas Kuesioner}

Validitas konvergen dapat dilihat dari nilai koefisien korelasi antara skor indikator reflektif dengan skor variabel latennya. Pada analisis faktor, hal ini dapat dilihat pada nilai muatan faktor (factor loading). Hair et al. (2010) memberikan rule of thumb muatan faktor dipandang bermakna jika lebih besar sama dengan 0,30 .

Tabel 4.2 Combine Loadings dan Cross Loadings

\begin{tabular}{|c|c|c|c|c|c|c|}
\hline & KSDM & SAP & SAKD & SPIP & KLKPD & $\begin{array}{c}\text { P } \\
\text { value }\end{array}$ \\
\hline KSDM1 & $\mathbf{0 . 6 3 1}$ & 0.128 & 0.094 & -0.156 & -0.332 & $<0.001$ \\
\hline KSDM2 & $\mathbf{0 . 5 9 2}$ & -0.143 & 0.261 & -0.138 & -0.065 & $<0.001$ \\
\hline KSDM3 & $\mathbf{0 . 6 0 0}$ & 0.103 & 0.227 & -0.020 & -0.356 & $<0.001$ \\
\hline KSDM4 & $\mathbf{0 . 7 5 3}$ & -0.081 & -0.098 & -0.142 & 0.187 & $<0.001$ \\
\hline KSDM5 & $\mathbf{0 . 7 9 8}$ & -0.118 & 0.096 & 0.135 & 0.054 & $<0.001$ \\
\hline KSDM6 & $\mathbf{0 . 7 2 0}$ & 0.166 & -0.075 & 0.263 & -0.033 & $<0.001$ \\
\hline KSDM7 & $\mathbf{0 . 7 5 6}$ & -0.115 & -0.489 & 0.044 & 0.189 & $<0.001$ \\
\hline KSDM8 & $\mathbf{0 . 6 3 1}$ & 0.102 & 0.111 & -0.049 & 0.252 & $<0.001$ \\
\hline SAP1 & -0.126 & $\mathbf{0 . 7 9 4}$ & 0.270 & 0.179 & -0.472 & $<0.001$ \\
\hline SAP2 & -0.089 & $\mathbf{0 . 7 6 0}$ & 0.573 & 0.071 & -0.570 & $<0.001$ \\
\hline SAP3 & -0.154 & $\mathbf{0 . 6 3 7}$ & 0.472 & 0.181 & -0.230 & $<0.001$ \\
\hline SAP4 & -0.024 & $\mathbf{0 . 6 5 3}$ & -0.090 & -0.133 & 0.317 & $<0.001$ \\
\hline SAP5 & -0.078 & $\mathbf{0 . 7 0 8}$ & 0.783 & -0.296 & -0.341 & $<0.001$ \\
\hline SAP6 & 0.039 & $\mathbf{0 . 5 3 3}$ & -0.114 & -0.200 & 0.340 & $<0.001$ \\
\hline SAP7 & 0.157 & $\mathbf{0 . 7 2 4}$ & -0.148 & -0.192 & -0.029 & $<0.001$ \\
\hline SAP8 & 0.233 & $\mathbf{0 . 6 8 9}$ & 0.304 & -0.631 & 0.201 & $<0.001$ \\
\hline SAP9 & 0.157 & $\mathbf{0 . 6 1 2}$ & 0.052 & -0.256 & 0.128 & $<0.001$ \\
\hline SAP10 & -0.098 & $\mathbf{0 . 5 2 6}$ & -0.344 & 0.048 & 0.021 & $<0.001$ \\
\hline SAP11 & -0.277 & $\mathbf{0 . 6 8 7}$ & -0.017 & 0.410 & -0.156 & $<0.001$ \\
\hline SAP12 & -0.371 & $\mathbf{0 . 7 6 1}$ & -0.091 & 0.367 & 0.165 & $<0.001$ \\
\hline SAP16 & 0.131 & $\mathbf{0 . 7 2 1}$ & -0.629 & 0.371 & 0.213 & $<0.001$ \\
\hline SAP17 & 0.038 & $\mathbf{0 . 7 8 8}$ & -0.515 & 0.288 & 0.252 & $<0.001$ \\
\hline SAP18 & 0.149 & $\mathbf{0 . 8 0 5}$ & -0.156 & 0.116 & -0.003 & $<0.001$ \\
\hline SAP19 & 0.271 & $\mathbf{0 . 8 3 4}$ & -0.328 & -0.422 & 0.280 & $<0.001$ \\
\hline SAKD1 & -0.053 & 0.509 & $\mathbf{0 . 7 6 7}$ & -0.025 & -0.257 & $<0.001$ \\
\hline SAKD2 & -0.078 & -0.183 & $\mathbf{0 . 8 5 9}$ & -0.063 & 0.187 & $<0.001$ \\
\hline Sumber: 019649619 & & & & \\
\hline
\end{tabular}

Sumber: Data olahan, 2019

Validitas diskriminan dapat dilihat dari nilai loading dan cross loading. Bilamana nilai loading setiap indikator pada variabel bersangkutan lebih besar dibandingkan dengan cross loading pada variabel laten lainnya maka dikatakan memenuhi validitas diskriminan. Bilamana akar AVE (pada diagonal utama) lebih besar dari korelasi 
variabel yang bersangkutan, maka terpenuhi validitas diskriminan (Solimun dan Fernandes, 2017).

Tabel 4.3 Akar AVE dan Koefisien Korelasi

\begin{tabular}{|c|c|c|c|c|c|}
\hline & KSDM & SAP & SAKD & SPIP & KLKPD \\
\hline KSDM & $\mathbf{0 . 6 8 9}$ & 0.457 & 0.491 & 0.403 & 0.446 \\
\hline SAP & 0.457 & $\mathbf{0 . 7 0 8}$ & 0.697 & 0.554 & 0.676 \\
\hline SAKD & 0.491 & 0.697 & $\mathbf{0 . 7 6 6}$ & 0.639 & 0.761 \\
\hline SPIP & 0.403 & 0.554 & 0.639 & $\mathbf{0 . 7 9 8}$ & 0.686 \\
\hline KLKPD & 0.446 & 0.676 & 0.761 & 0.686 & $\mathbf{0 . 7 8 3}$ \\
\hline
\end{tabular}

Sumber: Data olahan, 2019

\section{Reliabilitas}

Tabel 4.4 Composite Reliability dan Cronbach's Alpha

\begin{tabular}{|c|c|c|}
\hline Variabel & $\begin{array}{c}\text { Composite Realibility } \\
\text { Coefficiens }\end{array}$ & $\begin{array}{c}\text { Cronbach's Alpha } \\
\text { Coefficiens }\end{array}$ \\
\hline KSDM & 0.877 & 0.840 \\
\hline SAP & 0.940 & 0.932 \\
\hline SAKD & 0.876 & 0.822 \\
\hline SPIP & 0.913 & 0.929 \\
\hline KLKPD & 0.940 & \\
\hline
\end{tabular}

Sumber: Data olahan, 2019

1. Reliabilitas Komposit

Suatu kuesioner dikatakan memiliki reliabilitas komposit yang baik jika nilai composite reliability $\geq 0,70$ (Solimun dan Fernandes, 2017).

2. Reliabilitas Internal Konsistensi

Suatu kuesioner dikatakan memiliki reliabilitas internal konsistensi yang baik jika nilai cronbach,s alpha $\geq 0,60$ (Solimun dan Fernandes, 2017).

\section{Koefisien Variabel Laten}


Tabel 4.5 Koefisien Variabel Laten

\begin{tabular}{|c|c|c|c|c|c|c|c|c|}
\hline & KSDM & SAP & SAKD & SPIP & KLKPD & $\begin{array}{c}\text { KSDM } \\
\text { *SPIP }\end{array}$ & $\begin{array}{c}\text { SAP* } \\
\text { SPIP }\end{array}$ & $\begin{array}{c}\text { SAKD* } \\
\text { SPIP }\end{array}$ \\
\hline $\begin{array}{c}R \text {-Squared } \\
\text { Adj. } \text { - } \\
\text { Squared }\end{array}$ & & & & & 0.710 & & & \\
\hline $\begin{array}{c}\text { Full Collin } \\
\text { VIF }\end{array}$ & 1.591 & 2.515 & 3.163 & 2.163 & 3.147 & 1.827 & 2.717 & 2.196 \\
\hline \begin{tabular}{c} 
Q-Squared \\
\hline
\end{tabular} & & & & & 0.658 & & & \\
\hline
\end{tabular}

Sumber: Data olahan, 2019

$R$-squared untuk variabel kualitas laporan keuangan pemerintah daerah (LKPD) sebesar 0.710 yaitu sebesar $71 \%$ dan sisanya $39 \%$ dipengaruhi oleh variabel lain di luar model penelitian ini. adjusted $R$-squared untuk variabel kualitas laporan keuangan pemerintah pemerintah daerah (KLKPD) sebesar 0,688 yaitu sebesar 68,8\% dan sisanya $31,2 \%$ dipengaruhi oleh variabel lain di luar model penelitian ini. full collinearity test untuk semua variabel bernilai $<3,3$, sehingga model bebas dari masalah kolinearitas vertikal, lateral, dan common method bias. $Q$-squared menujukkan validitas prediktif yang baik karena 0,658 bernilai lebih besar dari nol.

\section{Hasil Pengujian Hipotesis}

Pengujian hipotesis dimaksudkan untuk membuktikan kebenaran dugaan penelitian atau hipotesis. Tingkat signifikansi yang digunakan dalam penelitian ini adalah sebesar $5 \%$ atau 0.05 . 
Tabel 4.6 Path Coefficients dan P Values

\begin{tabular}{|c|c|c|c|c|c|c|c|c|}
\hline \multicolumn{2}{|c|}{ Path coefficients } \\
\hline & KSDM & SAP & SAKD & SPIP & KLKPD & $\begin{array}{c}\text { SPIP* } \\
\text { SAKD }\end{array}$ & $\begin{array}{c}\text { SPIP } \\
\text { SA } \\
\text { P }\end{array}$ & $\begin{array}{c}\text { SPIP*K } \\
\text { SDM }\end{array}$ \\
\hline KLKPD & 0.033 & 0.258 & 0.527 & & & 0.175 & - & 0.183 \\
0.046 & & & \\
\hline & KSDM & SAP & SAKD & SPIP & KLKPD & $\begin{array}{c}\text { SPIP* } \\
\text { SAKD }\end{array}$ & $\begin{array}{c}\text { SPIP } \\
* \text { SAP }\end{array}$ & $\begin{array}{c}\text { SPIP*K } \\
\text { SDM }\end{array}$ \\
\hline KLKPD & 0.379 & 0.006 & $<0.001$ & & & 0.047 & 0.334 & 0.039 \\
\hline
\end{tabular}

Sumber: Data olahan, 2019

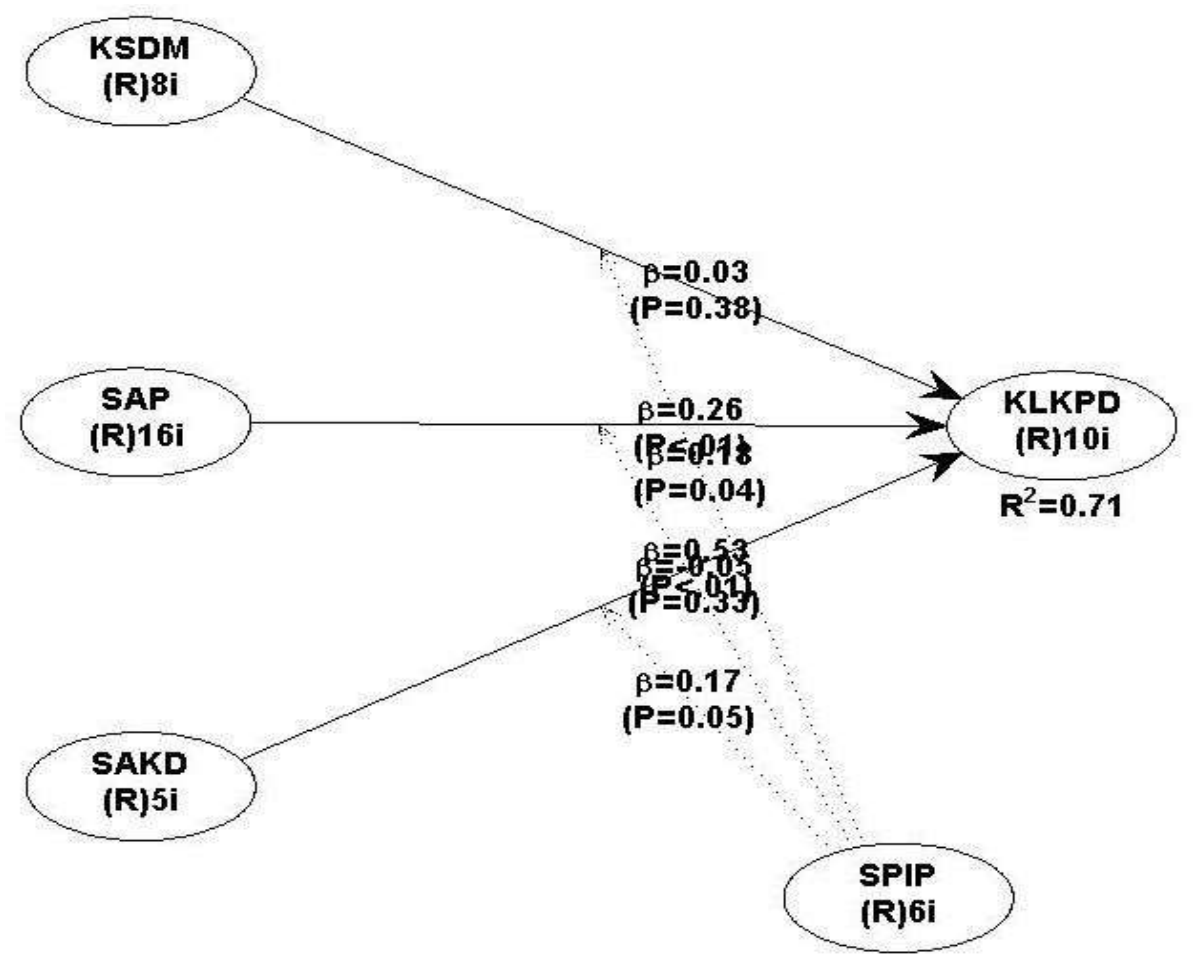

Gambar 4.1 Model Penelitian

Keterangan :

KSDM : Kompetensi Sumber Daya Manusia

SAP : Standar Akuntansi Pemerintahan

SAKD : Sistem Akuntansi Keuangan Daerah 
SPIP : Sistem Pengendalian Internal Pemerintah

KLKPD : Kualitas Laporan Keuangan Pemerintah Daerah

Dari tabel 4.6 diketahui bahwa hasil pengujian untuk variabel kompetensi sumber daya manusia rmenunjukkan nilai path coefficient sebesar 0.033 dengan nilai $p$-value 0.379 yang dimana lebih besar dari 0.05. Oleh karena itu dapat dinyatakan bahwa variabel kompetensi sumber daya manusia tidak berpengaruh terhadap kualitas laporan keuangan pemerintah daerah disimpulkan bahwa H1 ditolak.

Dari tabel 4.6 diketahui bahwa hasil pengujian untuk variabel standar akuntansi pemerintahan rmenunjukkan nilai path coefficient sebesar 0.258 dengan nilai $p$-value 0.006 yang dimana lebih kecil dari 0.05. Oleh karena itu dapat dinyatakan bahwa variabel standar akuntansi pemerintahan berpengaruh positif signifikan terhadap kualitas laporan keuangan pemerintah daerah disimpulkan bahwa $\mathrm{H} 2$ diterima.

Dari tabel 4.6 diketahui bahwa hasil pengujian untuk variabel sistem akuntansi keuangan daerah rmenunjukkan nilai path coefficient sebesar 0.527 dengan nilai $p$-value $<0.001$ yang dimana lebih kecil dari 0.05. Oleh karena itu dapat dinyatakan bahwa variabel sistem akuntansi keuangan daerah berpengaruh positif signifikan terhadap kualitas laporan keuangan pemerintah daerah disimpulkan bahwa $\mathrm{H} 3$ diterima.

Dari tabel 4.6 diketahui bahwa hasil pengujian untuk variabel sistem pengendalian internal pemerintah sebagai pemoderasi kompetensi sumber daya manusia menunjukkan nilai path coefficient sebesar 0.183 dengan nilai $p$-value 0.039 yang dimana lebih kecil dari 0.05. Oleh karena itu dapat dinyatakan bahwa sistem pengendalian internal pemerintah dapat memoderasi pengaruh kompetensi sumber daya manusia terhadap kualitas laporan keuangan pemerintah daerah secara positif signifikan disimpulkan bahwa H4 diterima.

Dari tabel 4.6 diketahui bahwa hasil pengujian untuk variabel sistem pengendalian internal pemerintah sebagai pemoderasi standar akuntansi pemerintahan menunjukkan nilai path coefficient sebesar -0.046 dengan nilai p-value 0.334 yang dimana lebih kecil dari 0.05. Oleh karena itu dapat dinyatakan bahwa variabel sistem pengendalian internal pemerintah tidak dapat memoderasi pengaruhstandar akuntansi pemerintahan terhadap kualitas laporan keuangan pemerintah daerah. Berdasarkan hasil tersebut disimpulkan bahwa H5 ditolak. 
Dari tabel 4.6 diketahui bahwa hasil pengujian untuk variabel sistem pengend alian internal pemerintah sebagai pemoderasi sistem akuntansi keuangan daerah menunjukkan nilai path coefficient sebesar 0.175 dengan nilai $p$-value 0.047 yang dimana lebih kecil dari 0.05. Oleh karena itu dapat dinyatakan bahwa sistem pengendalian internal pemerintah dapat memoderasi pengaruh sistem akuntansi keuangan daerah terhadap kualitas laporan keuangan pemerintah daerah secara positif signifikan disimpulkan bahwa H6 diterima.

\section{Pengaruh Kompetensi Sumber Daya Manusia terhadap Kualitas Laporan Keuangan Pemerintah Daerah}

Kompetensi sumber daya manusia tidak berpengaruh terhadap Kualitas Laporan Keuangan Pemerintah Daerah. Dengan demikian hipotesis pertama penelitian ini ditolak. Hal ini menunjukkan bahwa kompetensi sumber daya manusia tidak mempunyai pengaruh yang signifikan terhadap terciptanya laporan keuangan pemerintah daerah yang berkualitas. Ketidaksignifikanan ini mungkin disebabkan kondisi kompetensi sumber daya manusia di subbagian akuntansi/tata usaha keuangan yang belum mendukung. Hasil penelitian ini sejalan dengan penelitian Syarifudin (2014) yang menyatakan bahwa kompentensi sumber daya manusia tidak berpengaruh terhadap terciptanya laporan keuangan pemerintah daerah yang berkualitas. Namun hasil penelitian ini tidak sejalan dengan penelitian yang dilakukan oleh Pujanira (2017) yang menyatakan bahwa terdapat pengaruh positif yang signifikan terhadap kualitas laporan keuangan pemerintah daerah.

\section{Pengaruh Standar Akuntansi Pemerintah terhadap Kualitas Laporan Keuangan Pemerintah daerah}

Sistem akuntansi keuangan daerah berpengaruh positif signifikan terhadap kualitas laporan keuangan pemerintah daerah. Dengan demikian hipotesis ketiga ini di terima. Hal yang mendasar mempengaruhi kualitas laporan keuangan merupakan manfaat dari penerapan sistem akuntansi keuangan. Hasil penelitian ini sejalan dengan penelitian Pujanira (2017) yang menyatakan bahwa sistem akuntansi keuangan daerah berpengaruh positif signifikan terhadap kualitas laporan keuangan pemerintah daerah dan juga penelitian Permadi (2013) menyatakan hasil yang sama bahwa sistem akuntansi keuangan daerah berpengaruh positif secara signifikan terhadap kualitas laporan keuangan pemerintan daerah. Namun hasil penelitian ini tidak sejalan dengan penelitian 
Barus (2017) yang menyatakan bahwa tidak adanya pengaruh antara sistem akuntansi keuangan daerah terhadap kualitas laporan keuangan pemerintah daerah. Hal ini disebabkan masih belum sepenuhnya beberapa pemerintah daerah menerapkan sistem akuntansi keuangan daerah secara komprehensif dan efektif sehingga dapat menjadikan laporan keuangan kurang akurat dan belum berkualitas sepenuhnya.

Pengaruh Interaksi Kompetensi Sumber Daya Manusia dan Sistem Pengendalian Internal Pemerintah terhadap Kualitas Laporan Keuangan Pemerintah Daerah

Hasil uji moderasi kompetensi sumber daya manusia dan sistem pengendalian internal pemerintah terhadap kualitas laporan keuangan pemerintah daerah menunjukkan bahwa sistem pengendalian internal pemerintah mampu memoderasi pengaruh kompetensi sumber daya manusia terhadap kualitas laporan keuangan pemerintah daerah sehingga hipotesis keempat penelitian ini diterima yang menyatakan sistem pengendalian internal pemerintah memperkuat pengaruh kompetensi sumber daya manusia terhadap kualitas laporan keuangan pemerintah daerah. Hasil penelitian ini juga sesuai dengan yang di teliti oleh Diansyah (2019) yaitu adanya hubungan memoderasi antara kompetensi teknis aparatur sipil negara terhadap kualitas laporan keuangan pemerintah daerah. Namun penelitian ini tidak sejalan dengan hasil penelitian Barus (2017) yang dimana ketidaksejalanan dalam hasil penelitian ini disebabkan adanya perbedaan persepsi dari responden penelitian sewaktu pengisian kuisioner. Selain itu perbedaan waktu dan tempat dilaksanakannya penelitian jugadapat mempengaruhi ketidaksesuaian hasil penelitian yang di anggap bahwa sistem pengendalian internal pemerintah tidak mampu memoderasi interaksi antara kompetensi sumber daya manusia terhadap kualitas laporan keuangan pemerintah daerah.

Pengaruh Interaksi Standar Akuntansi Pemerintahan dan Sistem Pengendalian Internal Pemerintah terhadap Kualitas Laporan Keuangan Pemerintah Daerah

Hasil uji moderasi standar akuntansi pemerintahan dan sistem pengendalian internal pemerintah terhadap kualitas laporan keuangan pemerintah daerah menunjukkan bahwa sistem pengendalian internal pemerintah tidak mampu memoderasi pengaruh standar akuntansi pemerintahan terhadap kualitas laporan keuangan pemerintah daerah 
sehingga hipotesis kelima penelitian ini ditolak yang menyatakan sistem pengendalian internal pemerintah tidak dapat memperkuat pengaruh standar akuntansi pemerintahan terhadap kualitas laporan keuangan pemerintah daerah. Hasil penelitian ini sejalan dengan apa yang di teliti oleh Barus (2017) yang menyatakan bahwa sistem pengendalian internal pemerintah tidak dapat memoderasi hubungan antara standar akuntansi pemerintahan terhadap laporan keuangan pemerintah daerah yang berkualitas.Namun hasil penelitian ini tidak sejalan dengan yang di teliti oleh Achmad (2018) yang menyatakan bahwa sistem pengendalian internal pemerintah dapat memoderasi pengaruh di antara standar akuntansi pemerintahan terhad ap kualitas laporan keuangan pemerintah daerah.

Pengaruh Interaksi Sistem Akuntansi Keuangan Daerah dan Sistem Pengendalian Internal Pemerintah terhadap Kualitas Laporan Keuangan Pemerintah Daerah

Hasil uji moderasi sistem akuntansi keuangan daerah dan sistem pengendalian internal pemerintah terhadap kualitas laporan keuangan pemerintah daerah menunjukkan bahwa sistem pengendalian internal pemerintah mampu memoderasi pengaruh sistem akuntansi keuangan daerah terhadap kualitas laporan keuangan pemerintah daerah sehingga hipotesis keenam penelitian ini diterima yang menyatakan sistem pengendalian internal pemerintah memperkuat pengaruh sistem akuntansi keuangan daerah terhadap kualitas laporan keuangan pemerintah daerah. Hasil penelitian ini sejalan dengan hasil penelitian yang di peroleh Achmad (2018) yang menyatakan bahwa sistem pengendalian internal pemerintah dapat memoderasi hubungan antar sistem informasi akuntansi terhadap kualitas laporan keuangan pemerintah daerah. Namun hasil penelitian ini tidak sejalan dengan penelitian Arista (2018) yang menyatakan bahwa sistem pengendalian internal tidak mampu memoderasi hubungan di antara sistem akuntansi keuangan daerah terhadap kualitas laporan keuangan pemerintah daerah.

\section{SIMPULAN}

Berdasarkan hasil analisis dan pembahasan pada bab sebelumnya maka dapat ditarik kesimpulan sebagai berikut:

1. Kompetensi sumber daya manusia tidak berpengaruh terhadap kualitas laporan 
keuangan pemerintah daerah

2. Standar akuntansi pemerintahan berpengaruh positif secara signifikan terhadap kualitas laporan keuangan pemerintah daerah

3. Sistem akuntansi keuangan daerah berpengaruh positif secara signifikan terhadap kualitas laporan keuangan daerah

4. Sistem pengendalian internal pemerintah memoderasi pengaruh kompetensi sumber daya manusia terhadap kualitas laporan keuangan pemerintah daerah

5. Sistem pengendalian internal pemerintah tidak memoderasi pengaruh standar akuntansi pemerintahan terhadap kualitas laporan keuangan pemerintah daerah

6. Sistem pengendalian internal pemerintah memoderasi pengaruh sistem akuntansi keuangan daerah terhadap kualitas laporan keuangan pemerintah daerah

\section{Implikasi}

Berdasarkan hasil analisis dan pembahasan, impilikasi teoritis dan praktis dalam penelitian ini adalah:

1. Dapat memberikan masukan secara empiris kepada pemerintah Kabupaten Kubu Raya dalam rangka lebih mengoptimalkan kualitas laporan keuangan yang akan memotivasi para pegawai bagian keuangan di tiap OPD untuk mengevaluasi diri dalam meningkatkan kompetensinya dalam menyusun laporan keuangan.

2. Dapat menjadi pedoman bagi pemerintah Kabupaten Kubu Raya khususnya pada tiap OPD dalam membuat regulasi untuk menghasilkan laporan keuangan pemerintah daerah yang berkualitas, sehingga bermanfaat dalam meningkatkan kepercayaan masyarakat terhadap penggunaan angaran pemerintah daerah Kabupaten Kubu Raya.

\section{Keterbatasan}

Beberapa keterbatasan dalam penelitian ini adalah sebagai berikut:

1. Untuk penyebaran kuesioner mengalami keterhambatan karena tidak mencangkup secara keseluruhan sampel karena dari total 34 OPD yang terdaftar di pemerintah Kabupaten Kubu Raya, hanya 28 dengan persentase sebesar $82 \%$ yang dapat di jangkau karena kondisi geografis di daerah kabupaten Kubu Raya sehingga perlu membuthkan waktu dan dana transportasi yang cukup mahal.

2. Penelitian ini hanya menggunakan tiga variabel bebas yaitu kompetensi sumber 
daya manusia, standar akuntansi pemerintahan, sistem akuntansi keuangan daerah dan juga satu variabel moderasi yaitu sistem pengendalian internal pemerintah.

\section{Saran}

Berdasarkan keterbatasan penelitian yang telah disebutkan maka saran bagi penelitian selanjutnya adalah sebagai berikut:

1. Jumlah sampel dan tempat untuk penelitian selanjutnya bisa dapat dikembangkan dan perlu mencermati waktu yang tepat dalam penyebaran kuesioner dan juga lokasi yang ingin dijadikan tempat penelitian agar dapat memaksimalkan data yang diperoleh.

2. Kontribusi pengaruh variabel penelitian ini terhadap kualitas laporan keuangan pemerintah daerah adalah sebesar $71 \%$ dan sisanya $39 \%$ dipengaruhi oleh variabel lain di luar model penelitian sehingga perlu untuk menambahkan variabel-variabel lain yang tidak diuji dalam penelitian ini yang mungkin berpengaruh terhadap kualitas laporan keuangan seperti reviu laporan keuangan, peran audit internal dan juga pemanfaatan teknologi informasi.

3. Pada bagian kuesioner terdapat pilihan jawaban netral yang seharusnya netral tidak dijadikan pilihan jawaban bagi responden dikarenakan netral mengandung makna ganda sehingga untuk penelitian selanjutnya disarankan untuk mengganti pilihan jawaban netral menjadi cukup setuju

\section{REFERENCES}

Abdillah, W., \& Hartono, J. (2014). Partial Least Square (PLS). Yogyakarta: Andi.

Achmad, Nur Rahmasari. (2018). Faktor-Faktor Yang Mempengaruhi Kualitas Laporan Keuangan Dengan Sistem Pengendalian Internal Sebagai Variabel Moderating (Studi pada Kantor Wilayah Kementerian Agama Provinsi Sulawesi Selatan). Skripsi. Makassar: Universitas Islam Negeri Alauddin

Bastian, I. (2007). Sistem Akuntansi Sektor Publik Edisi 2. Jakarta: Salemba Empat

Bastian, I. (2010). Akuntansi Sektor Publik Suatu Pengantar. Edisi Ketiga. Bandung: Erlangga

Barus, Syarifuddin. (2017). Analisis Pengaruh Kompetensi Sumber Daya Manusia, Penerapan Standar Akuntansi Pemerintahan, Sistem Akuntansi Keuangan Daerah dan Pemanfaatan Teknologi Informasi Terhadap Kualitas Laporan Keuangan Pemerintah Kota Binjai Dengan Sistem Pengendalian Internal Pemerintah Sebagai Variabel Moderating. TESIS. Medan: Univsersitas Sumatera Utara

BPK RI. (2018). Ikhtisar Hasil Pemeriksaan Semester I Tahun 2017. Diakses dari www.bpk.go.id/ihps 
BPK-RI Kalimantan Barat. (2018). Penyerahan Laporan Hasil Pemeriksaan Atas Laporan Keuangan Kepada Sepuluh Pemerintah Daerah Tahun Anggaran 2017 di akses dari http://pontianak.bpk.go.id

BPKP. Peraturan Pemerintah No 60 Tahun 2008 tentang Sistem Pengendalian Internal. www.bpkp.go.id/public/upload/unit/sakd/files/PP60Tahun2008SPIP.pdf

Diansyah, Akil Syarif. (2019). Pengaruh Kompetensi Teknis Aparatur Sipil Negara, Sistem Informasi, Dan Reviu Laporan Keuangan Terhadap Kualitas Laporan Keuangan Pemerintah Daerah Dengan Variabel Moderasi Sistem Pengendalian Intern Pemerintah (Studi Empiris pada Pemerintah Kota Pontianak). Jurnal Ekonomi Bisnis dan Kewirausahaan (JEBIK). Pontianak: Universitas Tanjungpura.

Departemen Keuangan. Peraturan Pemerintah No 71 Tahun 2010 tentang Standar Akuntansi Pemerintahan. Diakses dari http://www.djpk.depkeu.go.id

Fuad, et, all., 2016. Pengantar Bisnis Edisi Revisi, Jakarta: PT Gramedia Pustaka Utama

Forum Dosen Akuntansi Sektor Publik. (2006). Standar Akuntansi Pemerintah Telaah Kritis PP Nomor 24 Tahun 2005. Yogyakarta: BPFE- YOGYAKARTA

Fakhrurrazy. (2009). Tentang penerapan Standar akuntansi pemerintah. Diakses dari http://fathrurazy. wordpress.com.

Ghozali, Prof. Dr. H. Imam, M. Com, Ak. (2006). Aplikasi Analisis Multivariat Dengan Program SPSS. Edisi Ketiga. Semarang: Universitas Diponegoro.

Ghozali, Prof. Dr. H. Imam, M. Com, Ak. (2011). Aplikasi Analisis Multivariate dengan Program IBM SPSS 19. Semarang: Universitas Diponegoro.

Gumelar, A. (2017). Pengaruh Kualitas Sumber Daya Manusia Penerapan Standar Akuntansi Pemerintahan dan Sistem Pengendalian Intern terhadap Kualitas Laporan Keuangan Pemerintah Daerah (Studi Empiris pada SKPD Kabupaten Kerinci).Skripsi. Padang: Universitas Negeri Padang

Hanaffi, R. (2017). Faktor - Faktor yang Mempengaruhi Kualitas Laporan Keuangan Pemerintah Daerah (Studi Empiris pada Satuan Kerja Perangkat Daerah Kabupaten Pati). Skripsi. Surakarta: Institut Agama Islam Negeri Surakarta.

Hair, Joseph, Iet.al. (2010). Multivariate Data Analysis $\left(7^{\text {th }} e d\right)$. New Jersey: Pearson Prentice Hall

Hasanah \& Fauzi. (2016). Akuntansi Pemerintahan. Jakarta: IN MEDIA

Humpro Kubu Raya. (2018). Kabupaten Kubu Raya Terima Hasil Pemeriksaan BPK RI. Diakses dari humpro.kuburayakab.go.id/berita/kubu-raya-terima- hasilpemeriksaan-bpk-ri

Jensen, M. C., \& Meckling, W. H. (1976). Theory of Firm: Managerial Behaviour, Agency Cost \& Ownership Structure. Journal of Financial Economics. Oktober. (Vol.3): No. 4: 305-306

Keputusan Kepala Badan Kepegawaian Negara No 46A Tahun 2007. Pedoman Penyusunan Standar Kompetensi Jabatan Struktural Pegawai Negeri Sipil. Diakses dari www.bkn.go.id/.../PERKA-BKN-NOMOR-13TAHUN-2011- PEDOMANPENYUSU...

Latifah, A. (2017). Pengaruh Penerapan Standar Akuntansi Pemerintah Sistem Akuntansi Keuangan Daerah Kompetensi Sumber Daya Manusia dan Sistem Pengendalian Internal terhadap Kualitas Informasi Laporan Keuangan Daerah 
(Studi Kasus pada SKPD Kabupaten Bantul). Jurnal Akuntansi dan Manajemen. Yogyakarta: Universitas PGRI

Mardiasmo. (2002). Akuntansi Sektor Publik. Yogyakarta: Andi Yogyakarta Mahardini, N.Y., \& Miranti, A. (2018). Dampak Penerapan Standar Akuntansi

Pemerintahan dan Kompetensi Sumber Daya Manusia pada Kualitas Laporan Keuangan Pemerintah Provinsi Banten Tahun Anggaran 2015. Jurnal akuntansi volume 5 nomor 1. Banten: Universitas Serang Raya

Nordiawan, D. (2006). Akuntansi Sektor Publik. Jakarta: Selemba Empat. Nawawi. (2001). Manajemen Sumber Daya Manusia untuk Bisnis yang

Kompetitif. Yogyakarta : Gajah Mada University Press

Octarinda, D.A. (2016). Pengaruh Kompetensi SDM, Penerapan Sistem Informasi Akuntansi Keuangan Daerah dan Sistem Pengendalian Intern Pemerintah terhadap Kualitas Laporan Keuangan Pemerintah Daerah Kabupaten Langkat. Skripsi. Medan: Universitas Sumatera Utara

Pujanira, P. (2017). Pengaruh Kompetensi Sumber Daya Manusia Penerapan Standar Akuntansi Pemerintahan dan Penerapan Sistem Akuntansi Keuangan Daerah terhadap Kualitas Laporan Keuangan Pemerintah Daerah Provinsi DIY. Jurnal nominal/volume vi nomor 2. Yogyakarta: Universitas Negeri Yogyakarta

Permadi, A. D. (2013). Pengaruh Penerapan Sistem Akuntansi Keuangan Pemerintah Daerah terhadap Kualitas Laporan Keuangan Pemerintah Daerah (Studi Kasus pada Dinas Bina Marga Provinsi Jawa Barat). Skripsi. Bandung: Universitas Widyatama.

Permendagri No 4 Tahun 2008. Pedoman Pelaksanaan Reviu atas Laporan Keuangan Pemerintah Daerah. Diakses dari http://keuda.kemendagri.go.id Peraturan Menteri Keuangan (PMK No. 59/PMK.06/2005). Sistem Akuntansi dan

Pelaporan Keuangan Pemerintah Pusat. Diakses dari

simpuh.kemenag.go.id/regulasi/pmk_59_05.pdf

Pontianak Post. (2018). Kubu Raya Kembali Raih WTP. Diakses dari https://www.pontianakpost.co.id/kubu-raya-kembali-raih-wtp)

Rahmawati, A. 2018. Pengaruh Penerapan Standar Akuntansi Pemerintah Pemanfaatan Teknologi Informasi dan Sistem Pengendalian Intern terhadap Kualitas Laporan Keuangan SKPD Kota Tangerang Selatan. Jurnal Ekonomi Bisnis dan Akuntansi (JEBA) volume 20 nomor 2. Purwokerto: Universitas Jendral Soedirman

Ryan Arista. (2018). Pengaruh Kompetensi Sumber Daya Manusia Penerapan Sistem Akuntansi dengan Sistem Pengendalian Intern Sebagai Variabel Moderasi Terhadap Kualitas Laporan Keuangan Pemerintah Daerah (Studi Pada Organisasi Perangkat Daerah Provinsi Riau). JOM FEB, Volume 1 Edisi 1 (Januari - Juni 2018). Pekanbaru: Universitas Riau

Roviyantie, D (2011). Pengaruh Kompetensi Sumber Daya Manusia dan Penerapan Sistem Akuntansi Keuangan Daerah terhadap Kualitas Laporan Keuangan Daerah (Survei pada Organisasi Perangkat Daerah (OPD) Kabupaten Tasikmalaya). Jurnal Universitas Siliwangi. Siliwangi: Universitas Siliwangi 
Rosalin, F. (2011). Pengaruh Penggunaan Teknologi Informasi dan Keahlian Pemakai terhadap Kualitas Informasi Akuntansi Studi pada BLU di Kota Semarang. Jurnal sistem informasi bisnis. Semarang: Universitas Diponogoro Rivai, V. (2011).

Rajawali pers.

Manajemen Sumber Daya Manusia untuk Perusahaan. Jakarta:

Rusvianto, D., Mulyani, S., \& Yuliafitri, I. (2018). Pengaruh Pelaksanaan Sistem Pengendalian Internal Pemerintah dan Kompetensi Sumber Daya Manusia terhadap Kualitas Laporan Keuangan Pemerintah Daerah (Studi Empiris pada SKPD Kota Bandung). Jurnal BanqueSyar'i volume 4 nomor 1. Bandung: Universitas Padjajaran

Sugiyono. (2014). Metode Penelitian Bisnis. Bandung: Alpha Beta.

Sangadji, M. E., \& Sopiah. (2010). Metodologi Penelitian-Pendekatan Praktis dalam penelitian. Edisi I. Yogyakarta: Andi

Sholihin, M., \& Ratmono, D. (2013). Analisis SEM-PLS dengan WarpPLS 3.0 untuk Hubungan Nonlinier dalam Penelitian Sosial dan Bisnis.Yogyakarta: Andi.

Syarifudin, M. (2014). Pengaruh Kompetensi SDM dan Peran Audit Intern terhadap Kualitas Laporan Keuangan Pemerintah Daerah dengan Variabel Intervening Sistem Pengendalian Internal Pemerintah (Studi Empiris pada Pemkab Kebumen). Jurnal Fokus Bisnis, Volume 14, No 02. Kebumen: Sekolah Tinggi Putera Bangsa

Septiani, A. (2005). Faktor-Faktor Yang Mempengaruhi Ketepatwaktuan Pelaporan Keuangan Pada Pasar Modal Yang Sedang Berkembang; Perpektif Teori Pengungkapan. Tesis. Semarang: Universitas Diponegoro

Saputra, B.W. (2015). Pengaruh Implementasi Standar Akuntansi Pemerintahan Sistem Informasi Akuntansi dan Sistem Pengendalian Internal terhadap Kualitas Laporan Keuangan Pemerintah Daerah (Studi pada SKPD Kota Pekanbaru). JOM FEKON volume 2 nomor 2. Pekanbaru: Universitas Riau

Solimun, Dr. Ir, MS., \& Fernandes, Dr. Adji. A. R, S.Si, M.Sc. (2017). Metode Statistika Multivariat Pemodelan Persamaan Struktural (SEM) Pendekatan WarpPLS. Malang: UB Press.

Yensi, D.S. (2014). Pengaruh Kompetensi Sumber Daya Manusia Penerapan Sistem Akuntansi Keuangan Daerah dan Sistem Pengendalian Intern (Internal Audit) terhadap Kualitas Laporan Keuangan Pemerintah Daerah (Studi Empiris pada SKPD Kabupaten Kuantan Singingi). JOM FEKON Volume 1 nomor Oktober 2014. Riau: Universitas Riau 